\title{
Calculation of road reliability based on mathematical theory of reliability
}

\author{
Vladimir Efimenko ${ }^{1, *}$, Rostislav Moisejenko ${ }^{1}$ \\ ${ }^{1}$ Tomsk State University of Architecture and Building, 634003 Tomsk, Russia
}

\begin{abstract}
The paper presents the mathematical theory of reliability as related to the theory of road reliability. The concepts of "initial reliability" and "durability" are combined in a single algorithm. The presented theoretical method is implemented in two stages: calculation of initial reliability and calculation of durability. This sequence enables analytical calculation at given levels of initial reliability and durability of roads and their elements. It is shown that initial reliability and durability should be calculated separately. This method has proved to be effective in applied sciences dealing with the theory of structural reliability.
\end{abstract}

\section{Introduction}

Russian and foreign scientists pay great attention to calculating the reliability of flexible pavements. The key findings are presented in works by N. N. Ivanov [1], I. A. Zolotar [2, 3], S. Yu. Rokas [4], V. A. Semyonov [5], V. V. Stolyarov [6, 7]. Some findings of foreign scientists can be presented in papers $[8,9]$.

In works by Russian authors, some terms adopted in the mathematical theory of reliability tend to be interpreted in a different way. These differences are reflected in regulatory documents. For example, mathematicians define the concept of reliability as follows [10]: "Reliability means the ability of a technical facility to maintain its characteristics (parameters) within certain limits under certain operating conditions". Experts A. M. Polovko and S. V. Gurov draw attention to a common mistake in papers of Russian researchers: the concept of reliability is associated with operating time of a facility [10]. Operating time of a facility is characterized by durability. This concept is defined as follows [10]: "Durability is the ability of a technical facility to remain serviceable before the onset of the critical condition, subject to the established maintenance and repair system".

In most publications dealing with road reliability, the term "durability" is not used at all, since the terms "reliability" and "durability" are combined into a single concept [2]: "The road reliability as an integrated transport facility is its ability to provide safe design traffic at an average speed close to the optimal one during its standard or specified service life".

V. V. Stolyarov $[6,7]$ even replaces the theory of reliability by the theory of risk. Using the "risk" as a synonym of "failure", his theory does not propose anything new. A. M. Polovko and S. V. Gurov emphasize [10]: "At present, there is no scientific theory of risk:

\footnotetext{
*Corresponding author: svefimenko_80@mail.ru
} 
fundamental concepts and definitions have not been formulated; mathematical models have not been developed; there is no engineering calculation method".

Incorrect formulations can lead to errors in calculating the reliability of structures. Therefore, it is important to further improve the theory of road safety. The solution of this problem will contribute, in particular, to formulation of the scientific language for the theory of road reliability. This language should correspond to other applied sciences dealing with the reliability of facilities and rely on the existing terms of the mathematical theory of reliability.

The aim of this study is to show that the road reliability can be calculated according to the general algorithm based on the existing mathematical theory of reliability.

\section{Methodology}

To achieve this aim, the following calculations were performed: (1) calculation of initial reliability (to determine the probability of failure-free operation $\left(P_{0}\right)$ at initial numerical characteristics of random variables); (2) calculation of durability (to determine the probability of failure-free operation during time t). As an example, parameters of flexible pavement are calculated according to permissible elastic deflection.

The first problem is solved in the following sequence. The strength condition of the road structure according to the permissible elastic deflection is written as [3]:

$$
E_{g e n} \geq E_{r e q} \text {. }
$$

As recommended by A. R. Rzhanitsyn [11], the condition (1) can be represented as:

$$
g=E_{g e n}-E_{r e q} \geq 0
$$

where $g$ is the bearing capacity reserve of a roadbed and pavement.

It is shown in [13] that the probability distribution function of random variables, such as elastic modulus, corresponds to the normal law.

The probability of failure-free operation (reliability index) under normally distributed random variables is calculated by the formula:

$$
P(g>0)=0,5+\Phi(\beta)
$$

where $\Phi$ is the Laplace integral; $\beta$ is the reliability index.

$$
\beta=\frac{\bar{E}_{g e n}-\bar{E}_{r e q}}{s_{g}},
$$

where $s_{g}$ is the standard deviation of the bearing capacity reserve; $\bar{E}_{g e n}$ is the average value of the elastic modulus of the road structure; $\bar{E}_{r e q}$ is the average value of the required elastic modulus.

The second problem is solved in the following sequence. Durability function has the form [14]: 


$$
P(t)=P_{0} e^{-\int^{t} \lambda(t) d t}
$$

where $\lambda(t)$ is the failure rate at time $t$.

The study [2] proves that the exponential law of failure rate is not applicable to calculating the reliability of roads. A number of studies $[4,5]$ note that the Weibull law is most appropriate for calculating parameters of roads [15]:

$$
\lambda(t)=\alpha \lambda t^{(\alpha-1)}
$$

where $\lambda$ is the parameter that has a dimension of failure rate $\left(y_{e a r}^{-1}\right) ; \alpha$ is the dimensionless parameter.

According to the expressions $(5,6)$, the durability function takes the form:

$$
P(t)=P_{0} e^{-\lambda t^{\alpha}}
$$

The mean time of failure-free operation is determined by the formula:

$$
T_{0}=P_{0} \int_{0}^{\infty} e^{-\lambda t^{\alpha}} d t
$$

\section{Results}

Let us consider an example of calculation according to the proposed approach. For comparative calculation, we consider the example presented in [12]. The initial data are presented in Table 1.

Table 1. Parameters of pavement layers and materials.

\begin{tabular}{|c|c|c|}
\hline Material & Layer thickness $h, \mathrm{~cm}$. & $\begin{array}{c}\text { Elastic modulus } E, \mathrm{MPa}, \\
\text { calculated according to } \\
\text { elastic deflection }\end{array}$ \\
\hline $\begin{array}{c}\text { Dense bituminous asphalt } \\
\text { concrete, grade BND 90/130 }\end{array}$ & 5 & 2,400 \\
\hline $\begin{array}{c}\text { Open-graded asphalt concrete } \\
\text { of the same grade }\end{array}$ & 6 & 1,400 \\
\hline $\begin{array}{c}\text { Graded crushed stone, } \\
40-80 \text { mm }\end{array}$ & 18 & 450 \\
\hline Crushed stone mix C1 & 16 & 300 \\
\hline Sand-and-gravel mix C4 & 22 & 275 \\
\hline Sandy loam, $\mathrm{Wp}=0.68 \mathrm{~W}_{\mathrm{T}}$ & - & 44.6 \\
\hline
\end{tabular}

By reducing multilayer pavement to two-layer one, we can calculate the parameters using the appropriate nomogram: $E_{\text {gen }}=312 \mathrm{MPa} ; E_{\text {min }}=202 \mathrm{MPa} ; K_{\text {str }}=1.54$.

To calculate the reliability by formulas $(3,4)$, it is necessary to determine the standard deviation $s_{g}[7]$ : 


$$
s_{g}=\sqrt{\left(C_{E_{g e n}} \cdot E_{g e n}\right)^{2}+\left(C_{E_{r e q}} \cdot E_{r e q}\right)^{2}}
$$

where $C_{E_{g e n}}$ is the coefficient of variation of the general elastic modulus of the pavement; $C_{E_{\text {req }}}$ is the coefficient of variation of the required elastic modulus of the structure.

The study [5] shows that if the probability of the random pavement parameter changes according to the normal law, then the coefficient of variation of this parameter is limited to $C_{g}<0.2$. Assume that $C_{E_{\text {gen }}}=0,19 ; C_{E_{\text {req }}}=0,15$. Then the standard deviation is

$$
S_{g}=\sqrt{\left(C_{E_{g e n}} \cdot E_{g e n}\right)^{2}+\left(C_{E_{r e q}} \cdot E_{r e q}\right)^{2}}=\sqrt{(0.19 \cdot 312)^{2}+(0.15 \cdot 202)^{2}}=66.57 \mathrm{MPa}
$$

According to the expression (4), the average value of the bearing capacity reserve of the road structure is equal to $\bar{g}=\bar{E}_{g e n}-\bar{E}_{r e q}=312-202=110 \mathrm{MPa}$. The reliability index is equal to:

$$
\beta=\frac{\bar{E}_{g e n}-\bar{E}_{r e q}}{s_{g}}=\frac{\bar{g}}{s_{g}}=\frac{110}{66.57}=1.65 .
$$

The probability of failure-free operation of the road structure is calculated by the formula (3):

$$
P(g>0)=0,5+\Phi(\beta)=0,5+\Phi(1.65)=0.5+0.4505=0.9505 .
$$

At the coefficient $K_{s t r}=1.54, P=0.9505$. According to Table 8.1 [12], at $K_{\text {str }}=1.29$, the probability of failure-free operation of the structure is equal to $P=0.98$. The discrepancy between the results is explained by different values of the coefficient of variation. The coefficients of variation can be calculated so that the calculated probability in the example will be greater than the tabulated probability.

However, the result in the example is not flawless, since the $E_{\min }$ module is determined at the total load for the entire service life of the road, while the $E_{\text {gen }}$ module is determined for the initial period of operation. Therefore, the difference $\left(E_{g e n}-E_{\min }\right)$, i.e. the bearing capacity reserve $(g)$, is overestimated, which leads to an increase in the reliability index $(\beta)$ and an increase in the probability of failure-free operation $(P)$.

For comparison, below is the calculation made using the Barber's formula, which approximates the nomogram for layer-by-layer calculation of pavement with sufficient accuracy [2]:

$$
E_{g e n}=\frac{E_{1} E_{2}\left[1+\left(\frac{2 h}{D}\right)^{2}\left(\frac{E_{1}}{E_{2}}\right)^{2 / 3}\right]^{1 / 2}}{E_{1}-E_{2}\left\{1-\left[1+\left(\frac{2 h}{D}\right)^{2}\left(\frac{E_{1}}{E_{2}}\right)^{2 / 3}\right]^{1 / 2}\right\}} .
$$

The calculation from bottom to top gives the following results: 5 th layer - soil $\rightarrow E_{\text {gen }}$ $=87.2 \mathrm{MPa}$; 4th-5th layers $\rightarrow E_{\text {gen }}=120.77 \mathrm{MPa}$; 3rd-4th layers $\rightarrow E_{\text {gen }}=179.54 \mathrm{MPa}$; 2nd-3rd layers $\rightarrow E_{\text {gen }}=208.412 \mathrm{MPa} ; 1$ st-2nd layers $\rightarrow E_{\text {gen }}=240.52 \mathrm{MPa}$; 
Recalculation of the probability gives the following result.

$$
\begin{gathered}
\bar{g}=\bar{E}_{g e n}-\bar{E}_{r e q}=240,52-202=38,52 \mathrm{MPa} \rightarrow \\
s_{g}=\sqrt{\left(C_{E_{g e n}} \cdot E_{g e n}\right)^{2}+\left(C_{E_{r e q}} \cdot E_{r e q}\right)^{2}}=\sqrt{(0,19 \cdot 240,52)^{2}+(0,15 \cdot 202)^{2}}=54,83 \mathrm{MPa} \rightarrow \\
\rightarrow \beta=\frac{\bar{g}}{s_{g}}=\frac{38,52}{54,83}=0,7 \rightarrow P(g>0)=0,5+\hat{O}(\beta)=0,5+\hat{O}(0,7)=0,5+0,258=0,758 .
\end{gathered}
$$

The results of calculations according to the nomogram and Barber's formula (10) differ significantly. Therefore, the conclusion about the sufficient accuracy of the Barber's formula [2] needs to be corrected.

Durability can be calculated by formulas $(6,7,8)$ at known values of the parameters $(\alpha$, $\lambda$ ) in the Weibull function (6). These parameters can be determined only by experiment $[5$, 16]. Despite numerous experimental studies of pavement strength published in the literature, the function of road failure rate has not been studied yet. This is due to the fact that the durability function (7) is not used in modern calculations of road safety at all.

To complete the example, approximate values are assigned to the parameters $(\alpha, \lambda)$. Assume that values of the failure rate function for the first and tenth years of operation are known: $\lambda(1)=0.001\left(\right.$ year $\left.^{-1}\right) ; \lambda(10)=0.1$ (year $\left.{ }^{-1}\right)$. Then, using the function (6), two equations are set up:

$$
\begin{aligned}
& \alpha \cdot \lambda \cdot 1^{(\alpha-1)}=0.001 . \\
& \alpha \cdot \lambda \cdot 10^{(\alpha-1)}=0.1 .
\end{aligned}
$$

From these equations, the roots can be determined: $\alpha=3, \lambda=0.000$ (3). The durability function (7) takes the form:

$$
P(t)=P_{0} e^{-\lambda t^{\alpha}}=0.9505 \cdot e^{-0,000(3) t^{3}}
$$

Subject to formula (8), the mean time of failure-free operation is calculated by the formula

$$
T_{0}=P_{0} \int_{0}^{\infty} e^{-\lambda t^{\alpha}} d t=0,9505 \int_{0}^{\infty} e^{-0,000(3) t^{3}} d t
$$

Numerical integration by trapezoidal method gives the result: $T_{0}=12.05$ (year). The obtained result agrees with the data in Table 4.6 [12], from which it follows that the service life of a projected road is $T_{s l}=12-16$ years. Therefore, the assumed values $\lambda(1)=0.001$ $\left(\right.$ year $\left.^{-1}\right) ; \lambda(10)=0.1\left(\right.$ year $\left.^{-1}\right)$ correspond to regulatory recommendations.

\section{Conclusion}

The paper shows that the mathematical theory of reliability is effective for calculating the reliability of roads. A large amount of statistical data accumulated in regions of Russia makes it possible to develop theoretical methods for calculating the reliability of pavements [12]. The theoretical method is implemented in two stages: calculation of initial reliability and calculation of durability. Only this sequence enables analytical calculation at given levels of initial reliability and durability of roads and their elements. 
The materials of the paper can be useful in developing new regulatory documents and conducting experimental studies to determine the parameters included in the failure rate function.

\section{References}

1. N.N. Ivanov, Konstruirovanie i raschjot nezhjostkih dorozhnyh odezhd [Design and calculation of flexible pavement] (Transport, Moscow, 1973) (in Russian)

2. I.A. Zolotar, V.K. Nekrasov, S.V. Konovalov, Yu.M. Yakovlev, M.S. Koganzon, Povyshenie nadjozhnosti avtomobil'nyh dorog [Improving of the road reliability] Повымение надёжности автомобильных дорог (Транспорт, Москва, 1977) (in Russian)

3. I.A. Zolotar, Obespechenie nadjozhnosti avtomobil'nyh dorog po prochnosti pri ih proektirovanii, stroitel'stve $i$ ekspluatacii [Ensuring the roads reliability for strength by their design, construction and operation] (Military Academy of Domestic Front and Transport, St. Petersburg, 1996) (in Russian)

4. S.Yu. Rokas, Statisticheskij kontrol' kachestva v dorozhnom stroitel'stve [Statistical quality control in road construction] (Transport, Moscow, 1977) (in Russian)

5. V.A. Semyonov, Kachestvo i odnorodnost' avtomobil'nyh dorog [Quality and roads homogeneity] (Transport, Moscow, 1989) (in Russian)

6. V.V. Stolyarov, Proektirovanie avtomobil'nyh dorog s uchjotom teorii riska [Design of highways with regard to the risk theory], part I (SSTU, Saratov, 1994) (in Russian)

7. V.V. Stolyarov, Proektirovanie avtomobil'nyh dorog s uchjotom teorii riska [Design of highways with regard to the risk theory], part II (SSTU, Saratov, 1994) (in Russian)

8. M.I. Dater, W.R. Hudson, R.C.G. Haas, Selection of optimal pavement designs considering reliability, performance and costs, in Transp. Res. Rec., 67-79 (1974)

9. M. Matsuo, K. Kuroda, Soils and Foundations, 14, 2 (1974)

10. A.M. Polovko, S.V. Gurov, Osnovy teorii nadjozhnosti [Fundamentals of the reliability theory] (BHV-Peterburg, St. Peterburg, 2006) (in Russian)

11. A.R. Rzhanitcyn, Teorija raschjota stroitel'nyh konstrukcij na nadjozhnost' [Calculating theory of structures for reliability] (Strojizdat, Moscow, 1978) (in Russian)

12. O.P. Afinogenov, V.N. Efimenko, S.V. Efimenko, Konstruirovanie i raschjot dorozhnyh odezhd [Designing and calculation of road pavement] (Kuzbassvuzizdat, Kemerovo, 2008) (in Russian)

13. V.K. Apestin, A.M. Shak, Yu.M. Yakovlev, Ispytanie i ocenka prochnosti nezhjostkih dorozhnyh odezhd [Tests and evaluation of the strength of non-rigid pavements] (Transport, Moscow, 1977) (in Russian)

14. Rekomendacii po ocenke nadjozhnosti stroitel'nyh konstrukcij [Recommendations for evaluation the reliability of building structures] (Uralskiy Promstrojniiproekt, Sverdlovsk, 1974) (in Russian)

15. B.V. Gnedenko, Yu.K. Belyaev, A.D. Solovyov, Matematicheskie metody v teorii nadjozhnost [Mathematical methods in the theory of reliability] (Nauka, Moscow, 1965) (in Russian)

16. S.I. Malafeev, Nadjozhnost' tehnicheskih sistem. Primery $i$ zadachi [Reliability of technical systems. Examples and tasks] (Lan Publ., St. Petersburg, 2012) (in Russian) 